\title{
Anti-establishment voting and Euroscepticism: The case of Italy and the Five Star Movement
}

\author{
GIOVANNI DI LIETO \\ Monash University \\ giovanni.dilieto@monash.edu \\ BRUNO MASCITELLI \\ Swinburne University of Technology \\ Bmascitelli@swin.edu.au
}

\begin{abstract}
This paper explores the meaning of the Italian anti-establishment voting and whether the Five Star Movement's anti-establishment label is appropriate. More specifically the investigation addresses the policies of the Five Star Movement towards the now creaking European Union, especially as growing Euroscepticism has been boosted by the Brexit referendum and the Trump dismissal and disdain for the European Union. In doing so, the paper examines the historic approach of so-called 'antiestablishment' parties that have had an almost 'normal' occurrence within the Italian political environment since the end of the Second World War. In this sense the paper concludes that addressing parties and systems as anti-establishment does little to help our understanding of this most fluid political period in Italy and across Europe.
\end{abstract}

Key words: Anti-establishment, populist, Euroscepticism, European Union, Five Star Movement, Italy

\section{Introduction}

The rejected Italian constitutional referendum in December 2016, preceded by the US presidential elections in November 2016 and before that the Brexit vote in June 2016, raised boundless political commentary across many divides. In Italy, this trend has opened the way to government for the oppositional Five Star Movement and the farright League after their stunning victory in the general election in March 2018. The need to define and explain these electoral results and the changing political mood of electorates recalls solutions and analysis which have the habit of seeking a catch all explanation. While there will always be similarities, care is required in not seeking a simplistic formula for all the events. Media commentary primarily, especially given the lack of scholarly analysis, is very quick to provide analogies and slogan solutions for the three electoral expressions. As the global broadcaster CNN divulged,'As happened with the outcomes of the Brexit vote in Great Britain and the Presidential election in the United States, this "No" vote [in the Italian referendum]carried with it an element of protest quite beyond the complicated political system reforms at hand' (Ben-Ghiat, 2016). Fortunately, even within the media outlets, this was a contested affirmation. According to Bloomberg: 
'It's tempting to plot a continuous line from the U.K.'s June vote to leave the European Union through to the election of Donald Trump to the Italian referendum on Sunday that ended Renzi's government and his hopes of changing politics in Italy. In each, populists won and establishment power was rejected. But Tolstoy's famous observation about families can be applied to elections: All victories are alike, but each loss is a failure in its own way' (Raphael, 2016).

Appearing in the descriptions on the lips of many observers, academic as well as journalistic, are the terms such as 'anti-establishment', 'populist' and 'anti-elite'. As another pundit observed in the case of the Italian 'No' vote in the referendum, 'The winds of change in western democracies have since whipped up into a storm and, as the Brexit vote and the election of Trump demonstrated, voters have stopped giving the answers their politicians expect' (Coman, 2016).

A feature of this debate on the voting patterns in 2016 is the question of leadership and bi-partisan politics. It would be an error to refer to the Brexit vote as an event which was entirely unexpected despite the shock it sent to the British government. There was in the case of Donald Trump a clear notation that he and Hillary Clinton were the two most unpopular politicians in the history of US elections. In the case of Matteo Renzi, his divisive dismissiveness of opponents and political arrogance irked many and in fact was ultimately punished by voters. In addition, in the case of the Brexit vote, the Cameron initiative to try and appease the right wing conservatives backfired in a context where decades of bi-partisan contempt for the European Union could only but produce this division and finally, an objection. All these cases bring to the fore the very role of political leadership. We are hearing now in the US that 'Obama paved the way for Trump' (Younge 2017). Many of the failings of the European Union are not just institutional in their nature but also due to a failure of vision, expectations and delivery. As the European Union even in its own words ${ }^{1}$ has failed to address the inequality in income and opportunity within its jurisdiction, its uninspiring leadership has done little to meet these challenges. Even the EU 'establishment' has continued to sell the same old stories with the same old recipes. At some point this nexus would be broken.

In the case of Italy, in December 2016, the Renzi government put forward a series of Constitutional changes. Amongst other things, it proposed the weakening of the Senate to allow the passing of laws with greater fluidity, with effectively only one house creating and passing laws. The referendum lost unambiguously with a margin of 20 percentage points (The Economist, 2016a). It not only produced a 'No' to the package of constitutional reforms, but also brought down the Renzi government. The 'No' vote in this case, like that of the Brexit and Trump elections in the US, is held up as an example of populism and anti-establishment voting patterns and, in the case of Italy, the Five Star Movement is held to be the key culprit behind this defeat. Literature on the Five Star Movement is vast and especially coinciding with the outcome of the 2013 elections. Studies such as Mosca 2013; Natale 2014; Diamanti 2014; Franzosi, Marone

\footnotetext{
${ }^{1}$ See the European Union White paper on the future of Europe and the way forward - Reflections and scenarios for the EU27. The White paper presented by the European Commission on 1 March sets out possible paths for the future of Europe. We face a great many challenges, from globalisation, to the impact of new technologies on society and jobs, to security concerns and the rise of populism. The White paper offered five scenarios for how the Union could evolve. See https://ec.europa.eu/commission/white-paper-future-europe-reflections-and-scenarioseu27_en.
} 
\& Salvati 2015, all highlight the ideologically transverse nature of this movement evolving at rapid speed.

\section{Relevant definitions and their various nuances}

Often the rush to explain political results, elections and otherwise, has produced simplistic catch-all labels. As a result, after the events of Brexit, the election of Trump and more recently the vote in the Italian referendum, many point the finger at political behaviours such as populism and voting against the establishment. Besides the very amorphous nature of populism, Pasquino (2008) refers to the "many definitions that have been offered...' providing a flavour that we are talking about a form of political behaviour. The term populism has sometimes been used to identify political formations, which are anti-establishment. Mazarr (2017) summarised the:

“...populist uprisings now under way in many countries around the world, which have been spurred on by outrage at increasing economic inequality, uneasiness with cultural and demographic changes, and anger at a perceived loss of national sovereignty" (Mazarr 2017: : 27).

Mudde has addressed the question of populism as being where "society ... [is] ultimately separated into two homogeneous and antagonistic groups" the people and the elite (cited in Krastev 2006). Referring to populism in the Italian context is both unhelpful and in our view incorrect politically. What is closer to the mark is the view of an 'anti-establishment' response, but even here we are faced with a range of historic inconsistencies and even framing a definition of the concept of 'establishment' and defining its antithesis. Moreover, with reference to the Five Star movement, we are obliged in some way to categorise this movement as 'anti-establishment' yet it is little different from many similar political movements in Italian modern history. As the next sections will explain and demonstrate, using 'anti-establishment' as a motivator and definition of a political movement is unhelpful in Italy. The Italian political system is historically littered with 'anti-establishment' parties which have primarily functioned as pressure instruments and in some cases as alternative and competing organisations for power.

\section{The Italian 'Establishment" and its Anti-Establishment}

Understanding the political 'establishment' in Italy is a tricky matter because of its distinctively local idiosyncrasies. Some pundits have sought to remind us after the failed constitutional referendum that Italy's equivalent to the so-called US antiestablishment Donald Trump is Five Star Movement's leader, Beppe Grillo. This parallel is rather arguable and even a miscalculated comparison. More likely the closest political equivalent to Trump in Italy has been Silvio Berlusconi and not only because of their shared high levels of wealth. They were both outsiders in terms of the political system, they were both in high-level business, and they both flouted the rules and defied previous protocols. They both challenged the structures in place: in the case of Trump, Washington and the Republican Party; in the case of Berlusconi, the Italian political system, the Vatican and others. Their personal political styles without doubt demonstrate the unorthodoxy of mixing government with their private businesses, their real and apparent conflict of interest, their use of close family and business structures to support their political leadership. To this extent, they were the 'antiestablishment'. 
In the case of Berlusconi, he brought into the government numerous company executives from the Italian (Berlusconi family-controlled) holding company, Fininvest. Trump has already shown similar behaviour and makes no apology for doing so. As noted in the aftermath of Trump's victory, '...the President-elect has surrounded himself with family members, donors and billionaires. He has assembled the wealthiest set of cabinet nominees in American history' (Hemmer, 2016). Both have contempt for the previous political protocol and both have rattled previous implied and expected relationships. Trump has challenged the Republican Party structures and routines, while Berlusconi was prepared to defy the approaches of both the previous governments and the Catholic Church - the latter a traditional ally of centre right governments. Berlusconi's debauched personal behaviour triggered this hostility between himself and the Catholic Church, and not just with Pope Francis. The main difference was that Trump is the President of a global superpower, of which Italy is a rather compliant ally.

\section{The Italian Republican Era - Littered with Anti-establishment Parties}

One scholar of Italian political systems points out that it would be mistaken to think that grassroots revolt against elites, as witnessed in Italy and elsewhere, is something new (Steinbock, 2016). Baldini notes that over the decades Italy has witnessed numerous forms of political opposition that would be considered anti-establishment responses. These include the anti-political and anti-communist 'Common Man's Front' (Uomo Qualunque), which took a million votes in the administrative elections of 1946. This organisation established by Guglielmo Giannini also produced the Italian term qualunquismo, which remained in the Italian political terminology as someone quite distrustful of the political system, the political parties, reverting to simplistic and conservative slogans on the issues facing the State and the government. In French politics, a similar term and usage emerged with the use of poujadisme named after Pierre Poujade, who in 1953 alongside a movement of petty bourgeois, shopkeepers and landlords criticised the political elites of the French Fourth Republic and their management of French national interests (Shields 2000).

In the 1970s, Marco Pannella's Radical Party fought hard in parliament and organised referenda on questions such as abortion, divorce and civil rights. Another antiestablishment contender, Silvio Berlusconi, came into the political fray as an 'outsider' pledging to clean up politics and run Italy like a business. Coman argues that 'Italy has witnessed regular crisis of legitimacy and waves of populism. It goes in cycles' (Coman 2016).

Using 'anti-establishment' as a definition for opposition to established parties brings on more problems than it solves. Looking back to the early days of the new Italian Republic of 1948, one can pinpoint anti-establishment parties across many divides. At the time, in as much as there was an 'establishment', it was the centre-right Christian Democracy, a faithful and loyal partner of US anti-communism in Europe in the Cold War struggle with the Soviet Union. The Italian Communist Party (PCI) and its postwar presence was de-facto declared to be an anti-establishment party, whether it considered itself to be one or not. This label of being anti-establishment was not a label the Italian Communist Party desired. In fact, it did its best to show it was as much prosystem or part of the establishment as possible. The task of demonstrating this was 
however rendered difficult by the Cold War geopolitics and the need to pursue anticommunist policies.

Even Italian political science scholars of the time like Giovanni Sartori argued that the Italian Communist Party was an anti-establishment party. Sartori, theorised and categorised in the 1960 s how the parties within the Italy's political system were characterised by a state of 'polarised pluralism', meaning that there were parties located politically across the ideological divide, which, in Italian was referred to as the arco costituzionale (i.e. constitutional arc). This ideological line stretched from extreme right to extreme left (Sartori 1976). Sartori's argument focused around three key political hubs: a centre around the Christian Democracy (DC); a far right around the Italian Social Movement (MSI) and far left around the PCI. He argued that only the centre was a pro-system grouping (another term for establishment) capable of governing while the other two were effectively anti-system (Sartori 1976).

Even before the end of the Cold War in Europe in 1989, the attempt by the 'anti-system' parties to legitimise themselves politically and become 'pro-system' was on full show. Throughout the 1970 s and 1980s, the PCI sought to join forces with the DC in order to be in government together to address the political and economic crisis which had afflicted Italy. The PCI, in this attempt to be pro-system, provided numerous descriptions of this act including 'government of national unity', 'government of national emergency', 'popular front' to name but a few (Spriano 1977). On the whole, these attempts failed and the PCI de facto remained 'anti-system'. In showing its loyalty to the 'establishment', the PCI spoke up for the role of NATO as the defender of Italy, it denounced the USSR for its intervention in Afghanistan in 1979 and it spoke out against Polish Communist Party leader General Jaruzelski who in 1981 declared martial law and banned the Polish Solidarnosc_(Kertzer 1996).

What is also evident is that similar steps towards acceptance and softening of the antiestablishment stance were also undertaken by the former neo-fascist Italian Social Movement (MSI) especially throughout the 1980s. The MSI moved towards the political centre and away from its extreme right-wing past, to the extent that in 1995 it changed key right wing aspects of its program and changed its name to Alleanza Nazionale (AN - i.e. National Alliance). The final step in this direction was when AN joined the centre-right coalition lead by Silvio Berlusconi in the early 1990 .

Another significant moment in Italy's political evolution involving so-called antiestablishment activities was the disappearance of Christian Democracy as a result of the anti-corruption investigations known as Tangentopoli (i.e. bribesville). Until 1992, the DC had ruled Italy without interruption since 1948. Much of this rule was in the guise of a weak establishment propped up by Cold War necessities and alliances. However, in 1990 the Cold War in Europe came to an end and to some extent so did the establishment (Mascitelli 2010). After the elections of 1992, where the DC still recorded 30 per cent of the vote, it was totally bypassed in the elections of 1994, won by Berlusconi's coalition, and the party went into liquidation. Overall what replaced the old DC was a myriad of centre factions and more importantly the new entrant in the field, Berlusconi's Forza Italia. Central to the allegations of corruption was the battle over political corruption and the so-called 'cost of democracy', which referred to the pilfering of the State coffers by the political parties in the parliament. The view espoused by some scholars (Calise, 1994; Bartolini et al, 2004) is that these party alliances were the source of mis-government and political corruption in Italy. These 
political forces all adapted to a more intransigent presence of the acceptable establishment (Riotta, 2012: 46).

In the period of Berlusconi's presence on the Italian political scene from the early 1990s, there was often an understanding that Berlusconi through his personal political party challenged the then 'establishment' replacing the Christian Democracy, which had been thus far the 'establishment'. Berlusconi, like Trump, did things his way and re-wrote many of the rules and contravened many of the practices and protocols (Day 2015). This renders the concept of anti-establishment complex and to some extent unusable as a definition that fits the context of Italy's first power transitions of the postwar era.

\section{The Renzi Referendum}

The referendum called in December 2016 contained a range of features, which revolved around the question of Italian parliamentary governance. In large part the referendum sought to alter the Senate and its function as the whereby both houses of parliament had equal rights and powers, what Italians called 'perfect bicameral system'. Therefore, the desire to change the role of the Senate to an unelected and appointed regional chamber provoked some concern. This paper cannot enter into detail on the nuances of the referendum. Whichever way the vote went, Italian parliamentary democracy would have remained pretty much the same. Therefore, why was the referendum important and why did it bring the resignation of the Prime Minister Renzi? In effect the referendum outcome, with an almost 60 versus 40 per cent opposition to it can hardly be categorised as either anti-establishment, populist or even anti-elitist.

The Renzi defeat went way far beyond the Five Star Movement's opposition. The parties, which were opposed to the referendum such as the Five Star Movement, Forza Italia, the Lega Nord (i.e. Northern League) and Italian Left, crossed the ideological divide of Italian politics and as such there was little surprise with the result. Renzi's own Democratic Party was split on the question, as were the left and the right; even Berlusconi's party was opposed. In addition, however, there were many institutional figures who all believed the proposal was a mistake and lacked legal legitimacy and foundations. Even The Economist, not known for left wing views, was against Renzi and stated: 'Mr. Renzi has already wasted nearly 2 years on constitutional tinkering. The sooner Italy gets back to real reform, the better for Europe' (The Economist, 2016b: 16). The referendum was complex, involved many aspects of the constitution, changing voting systems, altering the nature of the Senate and was all staked on the personal credibility of the Prime Minister. Moreover, Renzi was not a directly elected Prime Minister, but became so as a result of internal manoeuvres within the PD after the demise of the Mario Monti and later the Enrico Letta grand-coalition governments in 2013 .

\section{The Rise of the 'Anti-establishment' Five Star Movement}

While the origins of the Five Star Movement can be traced back to the creation of blogs and internet hubs in the period 2004-2005, one scholar estimates the electoral support for the Five Star Movement at that time reached no more than four per cent of the vote (Diamanti 2014). The Council Elections in 2009 and the decision by the then comedian Beppe Grillo to create this online movement was the moment this movement initially took off. It captured everyone's attention, however, when it really burst onto the scene 
in the 2013 elections (Franzosi et al 2015: Natale 2014). The elections were called after the then Prime Minister Mario Monti and his technical government lost political support in the Parliament and had no choice but to go to elections. In these elections, the Five Star Movement reached the unexpected status of the most voted for party of all parties, capturing 25.6 per cent of the vote, a result for a first-time presence which shocked political pundits. Besides collecting a protest vote, Diamanti pointed out that 'The $\mathrm{M}_{5} \mathrm{~S}$, indeed constitutes a strange case, hard to define. It is a movement, a party, but also simply a "vote" used by the citizens in a strategic or else in an expressive way...' (Diamanti 2014: 6). Given the peculiar nature of the Italian electoral system, in order to reach a majority a coalition is normally required, the Five Star Movement refused to join any and as a result was unable to form a majority and therefore missed out on having the right to form a government. Their program and positions were initially emotive and even populist. They simply wanted to 'send everybody home' meaning kicking out Italian political elite. Exponents of the media and the traditional parties even referred to the $\mathrm{M}_{5} \mathrm{~S}$ as 'fascists on the web' (Riotta 2012). But this was just another form of political simplification of the Five Star Movement, labelling an entity which was hard to define. Since then it has shaped Italian politics, especially parliamentary politics and broken many staid political traditions.

But is this behaviour so different from previous oppositions and/or governments? Five Star Movement, whatever it becomes, will not be what it is today. While it appears as an anti-establishment party, its main desire is to reform the political process, making it more accountable, reducing corruption and addressing issues that have impacted the daily lives of Italians. Unlike previous Socialist and Communist Parties which talked about the overthrow the system, nationalising the economy and giving more power to unions, the Five Star Movement says none of this and wishes simply to reform the political system, wishing to rid itself of corruption, self-interest and be more responsive to the populace. They are in effect erstwhile radical parties designed to keep the larger parties honest. The differences however are that they have gone one-step further and become a viable party of government. During the Council elections conducted in much of Italy while in opposition to Renzi's government, they assumed local government in politically sensitive cities such as Rome and Turin, and in the case of Turin they even captured a segment of the old working class (attached to FIAT) which turned its back on the Democratic Party. As captured by the conservative paper, The Economist, 'It was a 'clear and unmitigated defeat', in the words of the vanquished themselves: Italy's governing centre-left Democratic Party (PD)' (The Economist 20 June 2016c). With the referendum outcome, Renzi quickly offered his resignation and was replaced by his former Foreign Affairs Minister, Paolo Gentiloni. The new government that was sworn in, was a 'mirror copy' of the Renzi government with one ministerial reshuffle (Winfield 2016). The rise of the Five Star Movement reached its apex in the March 2018 elections. With nearly $33 \%$ of the votes, the Five Star Movement became by far the most successful Italian party and as such in May 2018 painstakingly formed a governing coalition with the other major winner of the elections, the (formerly Northern) League, which under Matteo Salvini's leadership achieved an unprecedented $17 \%$ of votes thanks to a renewed push of a sovereign populist platform. At last, Italy's purportedly anti-establishment has in effect laid the foundations for a new establishment, which the accidental coalition Five Star Movement-League has branded as the governo del cambiamento (i.e. the government of change).

\section{The 'anti-establishment' genesis of the Five-Star Movement (M5S)}


The Five Star Movement initially developed and communicated its limited policies through the eponymous blog of its co-founder, comedian and consumer protection activist, Beppe Grillo. Since its inception in 2004, the website beppegrillo.it has been the property of the company Casaleggio Associati, established and directed by the late co-founder of the Five Star Movement, Gianroberto Casaleggio who died in April 2016. There are scattered accounts of Casaleggio's activities before the 200os. According to both conspiratorial (Dezzani 2015) and mainstream media accounts, the Five Star Movement is not really anti-establishment, but 'has merely intercepted discontent to create its political franchise' (Wu Ming Foundation, 2013). Casaleggio's early professional career developed at Olivetti in the 1970s, where he met his first wife, British Elizabeth Clare Birks, and mother of Davide Casaleggio, who inherited the family company and currently runs the blog platform (Dezzani 2016). From Olivetti, in the early 2000s Casaleggio Sr then moved to become the head of the Italian operations of the British IT firm, Logica plc, famous for introducing Arpanet (the predecessor of internet) in Europe and for creating the SWIFT code of international money transfers between banks. In fact, in 1999 with a hostile takeover Olivetti acquired a 51 per cent share of Telecom Italia, the former state monopolist of telecommunication. Subsequently in 2000 Olivetti merged Logicasiel, bought from Logica Plc, and Finsiel, controlled by Telecom Italia, into a new company, Webegg Spa, specialising in the emerging field of taking businesses online. From 2000 to 2003 Casaleggio was managing director of Webegg Spa, in close professional proximity with key figures of the American business elite, such as Enrico Sassoon, board member of the American Chamber of Commerce in Italy and editor in chief of the Harvard Business Review Italy, and Rick Adam, founder of Neon, ex US Air Force officer, and then IT expert for Goldman Sachs and leading defence contractor Litton Industries/Northrop Grumman (Dezzani 2016). Olivetti lost control of Telecom Italia in 2001 to the advantage of Pirelli, which eventually sold Webegg Spa to Value Partners in 2004. The year before Casaleggio was ousted by Webegg Spa and thus set up his own company, Casaleggio Associati, with some of the Webegg executives, such as Luca Eleuteri and Mario Bucchich. The first venture of Casaleggio Associati was setting up Beppe Grillo's blog, taking it to become the seventh most popular in the world in only four years (Hooper 2013). But the Five Star Movement had anything but an anti-establishment beginning and its early members appear to be anything but anti-establishment. The fear that some have of the Five Star Movement and their labelling as anti-establishment derives from their apparent opposition to the European Union, to political protocol, and of course their objection to the referendum proposals presented by Renzi (Desideri 2018). Recent developments and policy pronouncements may indicate a different reading of the real positions of the Five Star Movement. Moreover, what policies and approaches of the Five Star Movement make it anti-establishment as some have indicated? The EU policy is one of the usual suspects, as the next section shows.

\section{The Five Star Movement and the question of the European Union}

The possibility of a Five Star Movement government would have been fanciful prior to 2013. This all changed when the Movement made a strong show at the elections to then become a possible party in contention for government. Virtually overnight, it became the party in Italy with the largest electoral base. Electoral polls, surveys and political forecasts appear to continue to support this notion. That this continued to be seen as a protest vote and an anti-elite movement is an error. Despite difficulties with Beppe Grillo, its inspirational leader, not being able to stand for elections, Grillo and Davide Casaleggio have groomed 'the 30-year-old deputy-speaker of the lower house, Luigi Di 
Maio ... as prime minister-in-waiting' (Follain \& Albanese 2016). This is despite all of the warnings about an inexperienced and poorly structured movement. Nevertheless, only events on the ground of actual government may prove these realistic concerns or show otherwise. The growing Euroscepticism in Italy is not a matter which is specific to the Five Star Movement. Since Italy entered the Eurozone in 1998, and alongside this, the evolution of Berlusconi's centre-right coalition (including the Northern League), Italy has seen itself move from a Europhile to a Eurosceptic member of the EU (Barbati 2014). This has coincided with an economy which has struggled with the new currency, facing greater economic hurdles, meetings its debt commitments, the impact of the Global Financial Crisis (GFC) and the slow return to growth. Moreover as exemplified by the Monti period of government following Berlusconi's defenestration in 2011, austerity was the only way Italy met these challenges which in large part explained the resounding defeat his government faced in the 2013 elections. Many economic indicators simply confirmed that Italy was suffering economically and, especially for the younger generations, recording 50 per cent unemployment and a significant lack of opportunities - all did not sit well for Italy's dunamics in the Eurozone. The Five Star movement is a product of this general economic discontent.

In line with this atmosphere, the Five Star movement since 2013 has variously pledged to hold another referendum on Italy's Eurozone membership. While Italy is not Britain, there is a sense that a result against the Euro is not a foregone conclusion. Winning that vote to exit the Eurozone in itself wouldn't be enough to break out of the European single currency, since for Italian law foreign treaties cannot be abrogated only with a referendum. Nor is there any guarantee that Five Star referendum would win such a vote, since polls show only a minority of Italians support a Euro exit (Follain $\&$ Albanese 2016). As one observer noted, the Five Star Movement leader has rejected that Euroscepticism and crisis can be blamed on the European Union:

'Luigi Di Maio, the deputy speaker of the Italian parliament, has emerged as the most likely figure to lead the $\mathrm{M}_{5} \mathrm{~S}$ at the next general election. He is critical of Brussels, but says the EU has become a scapegoat. It was very often used by Italian politics as an alibi, it's not guilty of everything it has been blamed for' (Scammell 2016).

Five Star leaders may have noticed that risky referendums can be hazardous to the political health of those who call them. On the other hand, the Five Star Movement's evolution in European politics, an E-U turn so to speak, signals that the Five Star Movement is open to negotiate with the so-called EU establishment, in other words those who advocate further economic integration in view of institutional federalism. This is particularly momentous as the crucial European Parliament election in May 2019 approaches. Grillo's attempt to reposition the movement's stance in Europe principally aims to show the 'establishment' that with the Five Star Movement in office in Italy, it would not be a destructive government for Europe, but a force able to catalyse reformist politics towards a more democratic direction for the EU.

\section{New meanderings of Euro-opportunism: The real face of the Five Star Movement?}

What became evident in January 2017, when in an unlikely push against the tide of Euro-scepticism (Di Lieto 2017), Beppe Grillo launched a primary vote on his eponymous blog to decide on the Five Star Movement group's membership in the 
European Parliament. The move was to be a precursor to a wholesale repositioning of the party's EU stance. More than 40,000 members of Grillo's digital platform cast their vote and nearly 80 per cent of them expressed a preference for the seventeen Five Star Movement Euro-parliamentarians to join the centrist pro-EU integration Alliance of Liberals and Democrats of Europe (ALDE), led by former Belgian Prime Minister, Guy Verhofstadt. After the last European Parliament elections in 2014, the Five-Star Movement controversially joined forces with Nigel Farage's UKIP to form a fiercely Eurosceptic parliamentary group named Europe of Freedom and Direct Democracy (EFDD). The nature and timing of the Five Star Movement digital primary vote caught both activists and pundits unaware. Contrary to the Five Star movement's signature claims of grassroots politics, Beppe Grillo's sudden move was essentially a top-down initiative pursued in secrecy. As the digital vote was launched on the blog without any prior debate, the Five Star Movement rank and file was thus presented with little more than a rubber stamp procedure of a decision already taken by the leader and his inner circle. Grillo revealed that he had also approached the European Greens group, but they refused the alliance with the Five Star movement in order to preserve their existing group dynamics. However, the ALDE's main powerbrokers stopped Verhofstadt's and Grillo's odd partnership. In response, Verhofstadt had to quickly release a statement to explain that: 'There is insufficient common ground to proceed with the request of the Five Star Movement to join the ALDE Group. There remain fundamental differences on key European issues. However, on issues of shared interest, such as the environment, transparency and direct democracy, the ALDE Group and the Five Star Movement will continue to work closely together' (Verhofstadt 2017).

Consequently, in January 2017 Grillo and Casaleggio had to appease Nigel Farage to re-enter the EFDD Group in order not to lose the funds linked to belonging to a parliamentary group. This was the second last voted option in the blog vote-albeit by only about 15 per cent of the members. On the surface, this awkward turnaround made Grillo's blog vote a useless if not politically detrimental exercise. Certainly, this created a certain embarrassment for the Five Star Movement leadership, as it added fuel to both internal criticism from anti-EU and populist hardliners (though they tend to be a minority component) and to external attacks from the pro-EU centrist Italian parties, which fear the Five Star Movement's encroachment in their political space. However, it is worth considering that Grillo may be playing an audacious, if expedient game of repositioning the Five Star Movement in the centre as a reformist force open to political alliances outside, but not against, the establishment, somewhat along the lines of Ciudadanos in Spain. It could be argued that Grillo was not really counting on being accepted by the rest of the ALDE Group, which is composed by a motley crew of small centrist, liberal and pseudo-progressive parties across the whole of Europe. This argument is supported by Grillo's indication to form a new political Euro-group called Direct Democracy Movement (DDM) - which featured in his blog post launching the primary vote online. This essentially signalled that either within or without the ALDE Group, the Five Star Movement is aiming to become a reformist force for a more democratic EU outside the establishment, but not destructively against it.

\section{The fall of a 'populist' Five Star Movement}

The Five Star Movement appears to possess some characteristics of an antiestablishment movement particularly in its genesis as a cross-ideological bundler and catalyst of deep-seated social discontent of Italians across many political divides 
(Diamanti 2014). Grillo, as a successful comedian, has been prolific in coining catchy slogans and insults that were artfully used to build a massive support base for the Five Star Movement. At first sight, the Five Star Movement may appear to also fulfil this marker, however, it may be argued that the change of tack in European policy shows that the Five Star Movement is moving away from antagonistic oppositions and towards the 'agonist pluralism' model of democracy described by Chantal Mouffe (2000) as one which maintains 'a distinction between the categories of enemy and adversary'. From this conceptual basis, Mouffe further notes that 'pluralist democracy is characterised by the introduction of a distinction between the categories of enemy and adversary. This means that within the "we" that constitutes the political community, the opponent is not considered an enemy to be destroyed but an adversary whose existence is legitimate' (Mouffe 2017). Indeed, the recent evolution as a governing force in coalition with a far-right party clearly shows that the Five Star Movement is now capable of engaging with the more nuanced politics of pluralist dealings with adversaries and allies rather than with binary enemies as it used to do in its early days.

The attempted repositioning by the Five Star Movement is equally reinforced by Grillo's 7-point agenda on the European Union published on the Five Star Movement's blog in the aftermath of the return to the fold of the EFDD. While appearing as little more than internal propaganda to reassure the Movement's base that it is not capitulating to the so-called establishment, it is revealing in terms of its clarity on the approach towards the European Union. Thus Grillo reassures his followers that the Five Star Movement EU policy agenda is (Grillo 2017):

1. Fiercely critical of the current role of the common currency, which serves Germany's interests and asphyxiates Italy's economic growth, so that a popular referendum on Italy's membership in the Eurozone should be called;

2. Instrumental in the likely rejection of the free trade initiatives such as the TTIP and the CETA, as well as against the recognition of China's market economy status (MES);

3. In favour of long-term bilateral agreements to solve the issue of unauthorised migration and facilitate immediate repatriations;

4. Against the oil and gas corporate lobbies that hinder Europe's transition to a policy of energy autonomy;

5. For strong initiatives to protect the environment and public health against corporate attacks;

6. For technological innovation and net regulation that improves the job prospects of young Italians; and

7. In favour of rescinding the commercial sanctions against Russia that are damaging the Italian SMEs, in recognition that Russia is an economic partner and anti-terrorism ally, not an enemy.

Without entering too much into the details of the above points, as this would require a separate study, at first glance it appears that only items 1 (Euro) and 2 (free trade) squarely fall into the current populist discourse, and even there arguably so. Opposition to the Euro in Italy parallels the period of conversion from Europhile to Eurosceptic, which involved other political entities including Berlusconi and his centre-right parties. Moreover, many other political movements including the European reformist/radical left (e.g. Corbyn, Varoufakis, Podemos, Greens) might find 
themselves in the company of the Five Star Movement (Mosca 2013). Not to mention items 3 to 6 which also cover pro-labour, pro-environment and anti-corporate matters that, bundles as they are, would hardly appeal to social conservatives and libertarians of the like of Nigel Farage, Frauke Petry and Geert Wilders. The last agenda item (proRussia) is the most controversial and escapes easy classification. It represents a feature of Italy's own approach towards Russia, which has sometimes been out of step with the EU's sterner and firmer position. Curiously, this position on Russia is highly inconsistent with the Movement's energy, civil rights and purported direct democracy agenda. Diplomats and pundits tend to agree that the Five Star Movement turned to a pro-Russia stance 'because they think it is politically advantageous. They are opportunistic. Tactically they feel this is a vote-getter' (Kirchgaessner 2017). Whatever it may be, it remains that there is no single thread in the EU policy of the Five Star Movement. This indicates that the movement leadership is up for grab, ready to sail wherever the winds of public opinion blow stronger.

\section{Conclusion}

We have seen that the Five Star Movement still dwells on polarised debates, but it is becoming capable of more nuanced political expediency to pursue power and get things done once in office. The bottom line is that the latest evolution of the Five Star Movement is well into the fold of a model of deliberative democracy that adopts 'agonistic pluralism' which can 'better envisage the main challenge facing democratic politics today: how to create democratic forms of identifications that will contribute to mobilise passions towards democratic designs' (Mouffe 2000:5). As a final check of the Five Star Movement's anti-establishment credentials, could it be argued that it is only evolving from a garden variety to a distinctively progressive type of oppositional role? Our answer is that it cannot, because the Five Star Movement is gradually forfeiting the antagonist frontier to keep hold of the government under conditions of agonistic pluralism. Judging also from Grillo's EU policy agenda, the political trajectory of the Five Star Movement does not fall squarely into a monolithic anti-establishment camp, neither politically nor ideologically, but it rather shows awareness of its own agonistic pluralism in a way that transcend its early anti-establishment aspirations. We have found instead that the Five Star Movement is increasingly displaying efforts to participate in a pluralistic regime, which typically comes into being not because of some pre-existing wide consensus on basic values, but rather as a result of a standoff between polarised worldviews (Hirschman 1991). Indeed, by holding on to the middle ground between sovereign populism and globalist mainstream, the Five Star Movement is more the natural heir of the Christian Democracy than of the purportedly anti-establishment Italian Communist Party. In the historical context of Italian politics, the 2018 power capture shows that the Five Star Movement is positioning itself as the indispensable, long-term governing partner well within and squarely across the whole constitutional arc.

In particular, we have argued that the Five Star Movement does indeed seek to appease the masses of people locked out of the access to what they perceive as the established power. However, its evolution shows that the Five Star Movement is not aiming to sweep away the institutions that are considered by its supporters the incarnations of a hostile establishment. Rather, as seen in the early stages of national government, as well as in the attempted EU parliamentary repositioning, the Five Star Movement is slowly unravelling the message to the non-establishment people that at some point 
their best chance of achieving some political influence will be to accept cooperation among competing elites and different institutions, be they established or emerging.

Further to this, we have identified the key factors of the Five Star Movement's genesis, evolution and constituency, showing that it too falls within the so called antiestablishment voting patterns that we identified in the historic context of Italy's Republican politics, from the post war entente of Catholics and communists up until Renzi's defenestration in the aftermath of the 2016 constitutional referendum. Hence, we could not easily pigeon-hole the Five Star Movement in the category of antiestablishment populism currently on the rise in Europe and across the Atlantic, as its leadership proves willing to engage in political compromise to enter the Italian, and European, constitutional arc. This has shown us that the Five Star Movement's vision is somewhat rooted in the awareness that the mass of non-establishment people is inherently barred from gaining control of a socio-political system in the pervasive and structured way that elites, oligarchies and tyrants can do (Crouch 2013).

Ultimately, it remains to be seen in practice whether Grillo and his inner circle act on genuine or rather expedient concern for their constituency, and to what extent they are consciously taking this trajectory upon becoming aware of the perennial conundrum of anti-establishment politics. This is the simple fact that in a real contestation with the various incarnations of the establishment, the non-establishment people either succumb to the elites thus loosing political voice entirely, or they sweep away the elites thus merely replacing them in the system.

\section{Bibliography}

Barbati J., 2014, Italy turns from one of the most pro-EU countries, to the most Eurosceptic, 21 February 2014, https://www.opendemocracy.net/can-europe-makeit/euro-elections-you-tell-us/jacopo-barbati/italy-is-quickly-turning-from-one-ofmost-pro-eu-countries-to-one-, viewed 31 January 2017.

Cartolini S. Chiaramonte A and D’Alimonte R., 2004, The Italian Party System between Parties and Coalitions, West European Politics, January 2004, Vol. 27, London, Taylor Francis.

Ben-Ghiat R., 2016, Meet Italy's Donald Trump: Italy's uncertain future, Five December, http://edition.cnn.com/2016/12/oFive/opinions/italy-beppe-grilloopinion-ben-ghiat/, viewed 20 December 2016.

Calise M. 1994, the Italian partitocracy: beyond President and Parliament, Political Science Quarterly 109, (3).

Coman J., 2016, First Brexit then Trump. Is Italy next for the west's populist wave? 27 November 2016, https://www.theguardian.com/world/2016/nov/27/matteorenzi-politics-italy-european-union-brexit-trump, viewed 19 December 2016.

Crouch C., 2013, Making Capitalism Fit for Society, London, Wiley.

Day M., 2015, Being Berlusconi: the rise and fall from Cosa Nostra to Bunga Bunga, Nero Melbourne, Vic. 
Desideri E., 2018, Eurosceptic or Europhile? Shedding light on the Five Star Movement's stance towards the EU, Open Europe, Five April 2018, https://openeurope.org.uk/today/blog/eurosceptic-or-europhile-shedding-light-onthe-five-star-movements-stance-towards-the-eu/, viewed 1Five September 2018.

Dezzani F., 201Five, M5S, la stampella del potere, 12 June 201Five, http://federicodezzani.altervista.org/mFives-la-stampella-del-potere/, viewed 27 January 2017.

Dezzani F., 2016, Addio a Gianroberto Casaleggio, l'anima "british" dek Movimento Five Stelle, 13 April 2016, http://federicodezzani.altervista.org/addio-a-gianrobertocasaleggio-lanima-british-del-movimento-Five-stelle/, viewed 27 January 2017.

Di Lieto G., 2017, Grillo's unlikely push against Euroscepticism, Australian Outlook, 10 January 2017, http://www.internationalaffairs.org.au/australian_outlook/grillosunlikely-push-against-the-tide-of-euroscepticism/, viewed 27 January 2017.

Diamanti I., 2014, The Five Star movement: A political laboratory, Contemporary Italian politics, Vol. 6. No. 1: pp. 4-1Five.

Follain J \& Alabanese C., 2016, Everything You Need to Know About Italy's Five Star Movement, 6 December 2016, https://www.bloomberg.com/news/articles/2016-12oFive/why-five-star-is-bane-of-italy-s-establishment-quicktake-q-a, viewed 2Five January 2017.

Franzosi P. Marone F. \& Salvato E., 2015, Populism and Euroscepticism in the Italian Five Star movement, The International Spectator, Vol. 50. No. 2 June 2015, pp. 109124 .

Grillo B., 2017, Il MoVimento Five Stelle: In Europa per l'Italia, Il Blog delle Stelle, 10 January 2016, http://www.ilblogdellestelle.it/il_movimento_Five_stelle_in_europa_per_litalia.ht ml, viewed 1 February 2017.

Hemmer N., 2016, Little joy in trump's new gilded age, The Age, 20 December, Fairfax Press, Melbourne.

Hirschman A.O., 1991, The Rhetoric of Reaction, USA, Harvard University Press.

Hooper J., 2013, Italy's web guru tastes power as new political movement goes viral, The Guardian, 3 January 2013, https://www.theguardian.com/world/2013/jan/o3/italy-five-star-movementinternet, viewed 27 January 2017.

Kertzer D., 1996, Politics and symbols: the Italian Communist Party and the fall of communism, London, Yale University Press.

Kirchgaessner S., 2017, Italy's Five Star Movement part of growing club of Putin sympathisers in West, The Guardian, Five January 2017, https://www.theguardian.com/world-/2017/jan/oFive/five-star-movement-beppegrillo-putin-supporters-west, viewed 13 January 2017. 
Krastev I., 2006, Democracy's “doubles”, Journal of Democracy, Volume 17, Number 2, April 2006, pp. 52-62.

Mascitelli B., 2010, Corruption, crisis and the end of the Cold War: Italy in the 1990s, Germany, Lambert Academic Publications.

Mazarr M., 2017, The once and fure order, Foreign Affairs, Jan-Feb 2017, Vol. 96, Issue 1, pp. 25-32.

Mosca L., 2013, The Five Star Movement: Exception or Vanguard in Europe? The International Spectator, December 2013.

Mouffe C., 2000, Deliberative Democracy or Agonistic Pluralism, Political Science Series 72, Institute for Advanced Studies, Vienna.

Mouffe C., 2017, Chantal Mouffe: Agonistic Democracy and Radical Politics, Pavilion Journal for politics and culture, 13 January 2017, http://pavilionmagazine.org/chantal-mouffe-agonistic-democracy-and-radicalpolitics/, viewed 27 January 2017.

Natale P., 2014, The birth, early history and explosive growth of the Five Star Movement, Contemporary Italian Politics, Vol. 6. No. 1: pp. 16-36.

Pasquino G., 2008, Populism and democracy in Ed. D. Albertazzi and D. McDonnell, Twenty-First century populism: The spectre of Western European democracy, UK, Palgrave Macmillan.

Raphael T., 2016, Don't confuse Italy with Trump, Five December, Bloomberg https://www.bloomberg.com/view/articles/2016-12-oFive/don-t-confuse-italy-withbrexit-or-trump, viewed 20 December 2016.

Riotta G., 2012, Stagioni del populismo Italiano, UK, Counterpoint.

Sartori G., 1976, Parties and Party Systems: A framework for analysis, Cambridge, UK Cambridge University Press.

Scammell R., 2016, No EU exit for us, say Italy's on-the-rise Eurosceptics, 19 July 2016, https://www.theguardian.com/world/2016/jul/19/no-eu-exit-for-us-sayitalys-on-the-rise-eurosceptics, viewed 31 January 2017.

Shields J., 2000, The Poujadist Movement: A faux 'fascism', Modern \& Contemporary France, 8:1, 19-34, http://www.tandfonline.com/doi/pdf/10.1080/o96394800113330?needAccess=true, viewed 31 January 2017.

Spriano P., 1977, Storia del partito comunista Italiano, Vol. 1-Five, Roma.

Steinbock D., 2016, The rise of anti-establishment Italy, http://www.economonitor.com/blog/author/dsteinbock), 8 December 2016, viewed 11 January 2017.

The Economist, 2016a, Salvaging the wreck, Editorial Commentary, 10 December 2016, London, The Economist. 
The Economist, 2016b, A regretful No, 26 November 2016, London, The Economist.

Verhofstadt G., 2017, Statement of the ALDE Group on cooperation with the Five Star Movement, ALDE Group, 9 January 2017, http://alde.eu/en/news/801-statementof-the-alde-group-on-cooperation-with-the-five-star-movement/, viewed 27 January 2017.

Winfield N., 2016, Italy's new government wins 1st of 2 confidence votes, Associated Press, December 13, 2016 http://www.startribune.com/new-italy-premier-designatefaces-confidence-votes-protest/406211606/, viewed 13 January 2017.

Wu Ming Foundation 2013, The Five Star Movement is not radical - Beppe Grillo is one of them, not us, The Guardian, 28 February 2013,

https://www.theguardian.com/comment-isfree/2013/feb/28/five-star-movementbeppe-grillo, viewed 27 January 2017.

Younge G., 2017, How Barack Obama paved the way for Donald Trump, The Guardian, 16 January,

https://www.theguardian.com/commentisfree/2017/jan/16/how-barack-obamapaved-way-donald-trump-racism 